Polónyi István ${ }^{1}$

\title{
A FELSŐOKTATÁS FEJLŐdÉSÉNEK INGADOZÁSAI FLUCTUATIONS IN THE DEVELOPMENT OF HIGHER EDUCATION
}

Ebben az írásban a felsőoktatás fejlődésében tapasztalható ingadozásokat elemezzük. Az elemzés a felsőoktatás elmúlt mintegy ötven évének hazai és nemzetközi fejlödését veszi górcső alá, s arra keresi a választ, hogy az autonómia mennyiben befolyásolja a felsőoktatási részvétel ingadozásait. A felsőoktatás teljes részvételi arányának növekedésében tapasztalható ingadozások nemzetközi összehasonlításban azt mutatják, hogy a magyar ciklikusság az egyik legnagyobb mind 1970 elött, mind 1987 után. Az államszocialista idöszak felsőoktatási ciklikussága régről ismert jelenség [Bauer, 1981; Bródy, 2000], ugyanakkor az ezredforduló után tapasztalható ingadozásnak kevésbé vizsgáltak az okai. Vizsgálatainkat úgy interpretálhatjuk, hogy a felsőoktatás teljes részvételi hányadának éves ingadozásait a GDP és a releváns korosztály létszámának éves ingadozásai növelik, az egyetemi autonómia pedig csökkenti. Elemzésünk tehát arra utal, hogy ezeknek az ingadozásoknak a GDP és a korosztályi létszám ingadozásai mellett a felsőoktatási intézmények autonómiájában - annak korlátozásában - lelhetők meg a magyarázatok.

In this paper, we analyze the fluctuations in the development of higher education. The analysis examines the domestic and international development of the past fifty years of higher education and seeks to answer the question of the extent to which autonomy influences fluctuations in higher education participation. Fluctuations in the increase in the total participation rate of higher education in international comparison show that Hungarian cyclicality is one of the largest, both before 1970 and after 1987. The cyclical nature of higher education in the state socialist period has long been a known phenomenon (See Bauer 1981, Bródy 2000), however, the reasons for the fluctuations experienced after the turn of the millennium have been less studied. Our studies can be interpreted as meaning that the annual fluctuations in the total participation rate of higher education are increased by the annual fluctuations in GDP and the number of people in the relevant age group, while the fluctuations in the participation rate are reduced by university autonomy. Our analysis thus suggests that the reasons for these fluctuations are explained by fluctuations in GDP and age group, as well as by the limitation of the autonomy of higher education institutions.

\footnotetext{
${ }^{1}$ egyetemi tanár, Debreceni Egyetem Nevelés- és Művelődéstudományi Intézet Neveléstudományi Tanszék
} DOI: 10.14267/RETP2020.04.08 
Ebben az írásban a felsőoktatás fejlődésében tapasztalható ingadozásokat elemezzük. Az elemzés a felsőoktatás elmúlt mintegy ötven évének hazai és nemzetközi fejlődését veszi górcső alá, s arra keresi a választ, hogy az autonómia mennyiben befolyásolja a felsőoktatási részvétel ingadozásait.

\section{A FELSŐOKTATÁS FEJLŐdÉSE}

A múlt század közepén elkezdődött tömegesedés nyomán megindult a felsőoktatás általánossá válása.

A Világbank adatai szerint a 2010-es évek végén Svájcban a legmagasabb, 37\% a 25 éves és idősebb felsőfokú végzettséggel ${ }^{2}$ rendelkező népesség aránya ${ }^{3}$, ezután következik Litvánia, az Egyesült Államok és Izrael kicsit több mint 33\%-kal ${ }^{4}$. Magyarország a kelet-európai térséghez hasonlóan alig több mint 20\%-os arányával az 50 legfejlettebb ország ${ }^{5}$ között (illetve az azok közül adatot közlő 39 közül) a 24. helyen áll.

1. ábra A 15 éves és idősebb népességen belül a diplomások (Post secondary és magasabb végzettségűek) aránya régiónként és Magyarországon

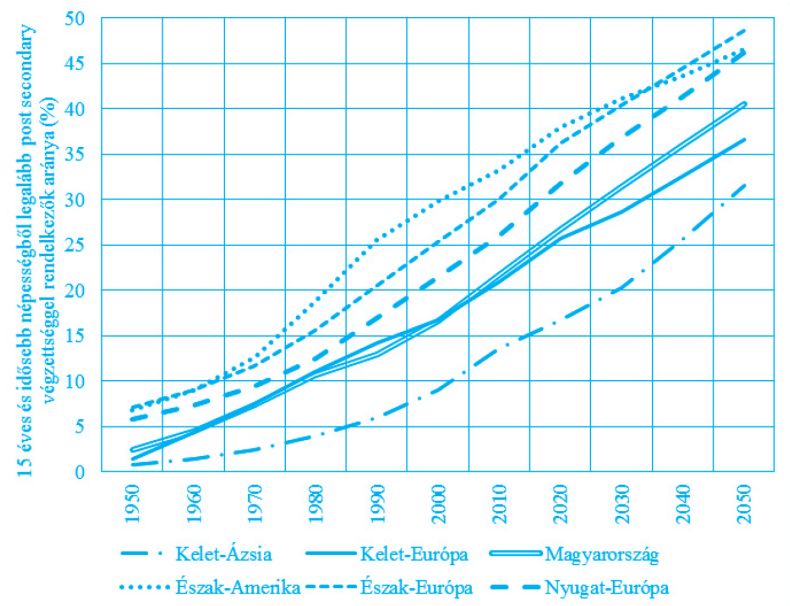

Forrás: Wittgenstein Intézet adatai (www.wittgensteincentre.org/dataexplorer) alapján saját szerkesztés

Ha az Európa 2020 stratégia által használt fiatal (30-34 éves) korosztályban vizsgáljuk a felsőfokú végzettségűek arányát, akkor 2019-ben nyolc EU-tagországot találunk, ahol a felsőfokú végzettségüek aránya meghaladja az 50\%-ot. ${ }^{6}$

\footnotetext{
${ }^{2}$ Legalább Bachelor vagy azzal egyenértékü végzettségü (Educational attainment, at least Bachelor’s or equivalent, population $25+$, total (\%) (cumulative))

${ }^{3} 2015$. évi adat

${ }^{4}$ Litvánia és USA 2016. évi, Izrael 2015. évi adat

${ }^{5} \mathrm{Az} 50$ legfejlettebb ország alatt az OECD, az EU és a G20 országait együttesen értjük itt.

${ }^{6}$ Tertiary educational attainment (\% of population aged 30 to 34 ) https://ec.europa.eu/eurostat
} 
A Wittgenstein Intézet előjelzése szerint a 21. század közepén a világ számos régiójában a felsőfokú végzettségüek ${ }^{7}$ aránya a 20-64 éves népességen belül eléri az 50\%-os (a század végére pedig meghaladja a 60\%-os) arányt. (1. ábra)

A felsőoktatás tehát lassan általánossá válik, lényegében a 21. század végén annyian szereznek majd diplomát, mint manapság érettségit.

\section{A NÖVEKEDÉS INGADOZÁSAI}

Ha részleteiben is megvizsgáljuk a felsőoktatás növekedését, korántsem annyira sima fejlődést látunk, mint azt a korábbi ábra mutatja. Három olyan ország (amelyiknek interneten jól elérhető a történelmi statisztikája) hosszú időtávra vonatkozó adatait mutatja be a 2. ábra. Elég egyértelmüen látszik, hogy mindegyik országban igen jelentős ingadozásokat találunk, amelyek között a magyar a legnagyobb.

2. ábra A felsőoktatási hallgatólétszám éves változása az előző évihez viszonyítva három országban (USA, Magyarország és (Nyugat)Németország) 1950-2018

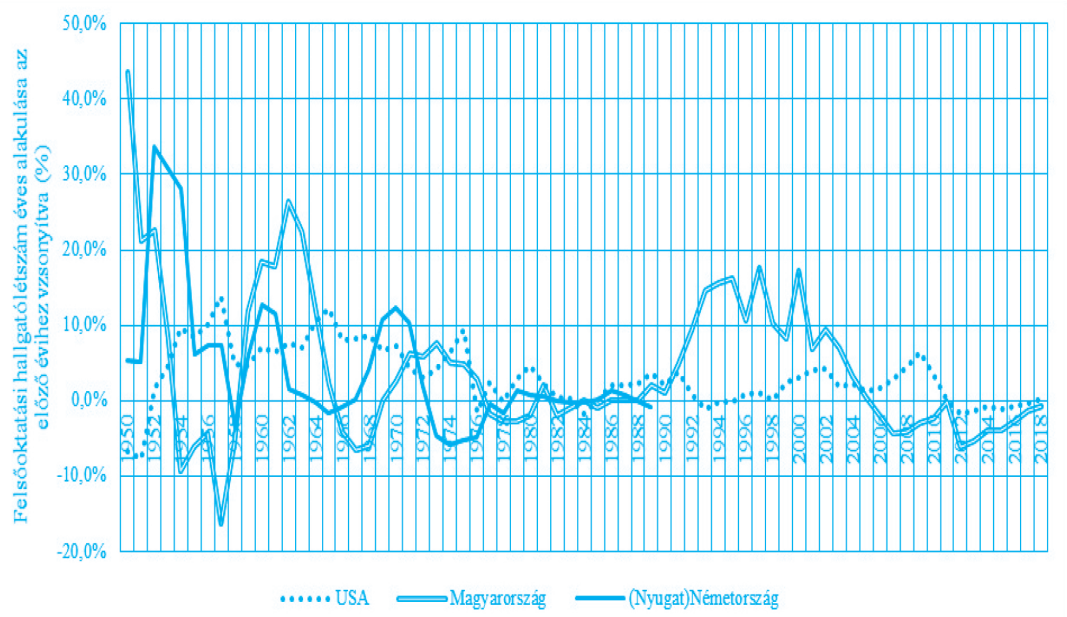

Források: USA: Snyder Th. D (ed 1993) 120 Years of American Education: A Statistical Portrait. National Center for Education Statistics https://nces.ed.gov/pubs93/93442.pdf ,, valamint Digest of

Eduaction Statistics IES-NCES https://nces.ed.gov/programs/digest/d18/tables/dt18_303.10.asp Németország: André Steiner (2006) Statistische Übersichten zur Sozialpolitik in Deutschland seit 1945 https://www.bmas.de/SharedDocs/Downloads/DE/PDF-Publikationen/fb-f352-statistische-uebersichten-zur-sozialpolitik-in-deutschland-seit-1945.pdf?_blob=publicationFile\&v=2

Magyarország: Magyarország népessége és gazdasága, Múlt és jelen, KSH 1996., illetve KSH.hu

\footnotetext{
${ }^{7} \mathrm{Az}$ adatbázis az országok nagyobbik részében a középfokúnál magasabb (post secondary) végzettségűek arányát becsli előre. Egyes országoknál megadja a Bachelor és a Master végzettségüek arányát is. Így pl. Finnországban 43\% lesz BA és 24\% MA, Hollandiában 47\% lesz BA és 26\% MA végzettségü.
} 
Az átlagos növekedéstől való eltérés átlagát 1950 és 2018 között tízéves átlagok alapján vizsgálva (1. táblázat és 3. ábra) megállapíthatjuk, hogy a három összehasonlított ország közül Magyarországon a legnagyobb az ingadozás (azaz az átlagos növekedéstől való átlagos eltérés) ${ }^{8}$.

1. táblázat A hallgatólétszám-növekedés hosszú távú átlagai és az átlagától való eltérés átlagai

\begin{tabular}{|c|c|c|c|c|c|c|c|c|c|c|}
\hline & & 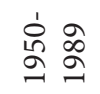 & $\begin{array}{l}1 \\
\stackrel{2}{2} \\
\stackrel{1}{0}\end{array}$ & 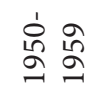 & ㅎํㅇ & 옹 & $\begin{array}{l}\dot{1} \\
\infty\end{array}$ & ஓু হ & ঠి ঠి ঠ & 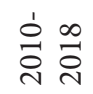 \\
\hline \multirow[t]{2}{*}{ USA } & $\begin{array}{l}\text { Átlagos } \\
\text { növekedés (\%) }\end{array}$ & $4,5 \%$ & $3,2 \%$ & $4,3 \%$ & $8,2 \%$ & $3,8 \%$ & $1,6 \%$ & $0,9 \%$ & $3,2 \%$ & $-0,3 \%$ \\
\hline & $\begin{array}{l}\text { Átlagos eltérés } \\
\text { az átlagtól (\%) }\end{array}$ & $3,6 \%$ & $3,2 \%$ & $5,2 \%$ & $1,3 \%$ & $2,5 \%$ & $1,5 \%$ & $1,1 \%$ & $1,3 \%$ & $1,0 \%$ \\
\hline \multirow[t]{2}{*}{$\begin{array}{l}\text { Magyar- } \\
\text { ország }\end{array}$} & $\begin{array}{l}\text { Átlagos } \\
\text { növekedés (\%) }\end{array}$ & $4,3 \%$ & $4,1 \%$ & $6,5 \%$ & $8,2 \%$ & $2,8 \%$ & $-0,2 \%$ & $10,8 \%$ & $3,1 \%$ & $-3,0 \%$ \\
\hline & $\begin{array}{l}\text { Átlagos } \\
\text { eltérés az } \\
\text { átlagtól (\%) }\end{array}$ & $8,4 \%$ & $7,7 \%$ & $14,9 \%$ & $11,2 \%$ & $3,2 \%$ & $1,0 \%$ & $4,1 \%$ & $5,7 \%$ & $1,7 \%$ \\
\hline \multirow[t]{2}{*}{$\begin{array}{l}\text { Német- } \\
\text { ország }\end{array}$} & $\begin{array}{l}\text { Átlagos } \\
\text { növekedés (\%) }\end{array}$ & $4,2 \%$ & & $12,7 \%$ & $3,9 \%$ & $0,3 \%$ & $0,2 \%$ & & & \\
\hline & $\begin{array}{l}\text { Átlagos eltérés } \\
\text { az átlagtól (\%) }\end{array}$ & $6,4 \%$ & & $11,0 \%$ & $4,8 \%$ & $4,9 \%$ & $0,5 \%$ & & & \\
\hline
\end{tabular}

Források: 2. ábra adatai alapján saját számítás

3. ábra A hallgatólétszám-növekedés tízéves átlagai és az átlagától való eltérés átlagai 1950-2018

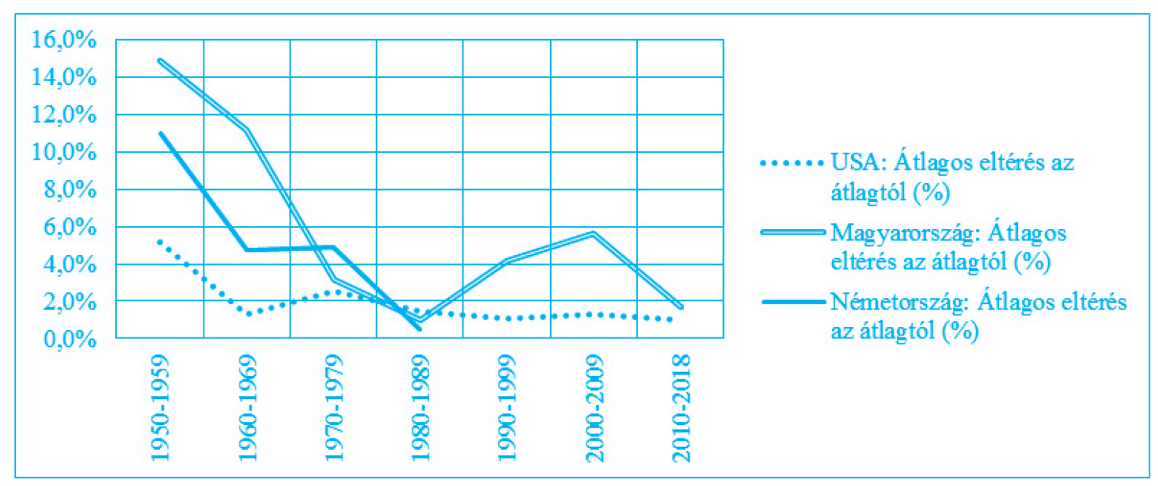

Források: 2. ábra adatai alapján saját számítás

${ }^{8}$ Jelen tanulmányban az ingadozás mértékét az átlagos eltéréssel jellemezzük. Az átlagos eltérés $\mathrm{AE}=\left(\sum\left|\mathrm{x}_{\mathrm{i}}-\overline{\mathrm{x}}\right|\right) / \mathrm{n}$ Miután az átlagos növekedés \%-ban megadott érték, az átlagos eltérés is \%-ban fog adódni. 


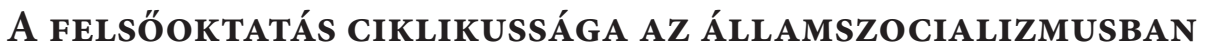

A felsőoktatás ciklikussága korántsem ismeretlen jelenség államszocializmus idején. Az államszocialista rendszerben a beruházások alakulása törvényszerüen ciklikus, s így a „tervezett” felsőfokú szakemberek iránti kereslet is hasonló.

Bauer Tamás [1981] bizonyítja, hogy az államszocialista tervgazdaság viszonyai között törvényszerü a beruházások ciklikussága. A beruházási ciklusok miatt a felsőfokú szakemberek iránti (tervezett) kereslet is ciklikus (lásd még erről [Bródy, 2000]). A beruházási fellendülés időszakában szakemberhiány, a beruházások visszafogásának időszakában pedig túlkínálat lesz, így a fellendülés során a szakemberhiány (és a képzés felgyorsítása, lerövidítése miatt minőségrontás), a visszafogás során az inkongruens foglalkoztatás termelődik újra. Tehát a központi tervgazdálkodás törvényszerűen hordozza magában a ciklikusságot: a szakemberhiány, és vele a képzési minőségrontás, valamint az inkongruencia újratermelődését [Polónyi, 2016].

\section{4. ábra A hazai felsőoktatási hallgatólétszám és a beruházási ciklus összefüggése}

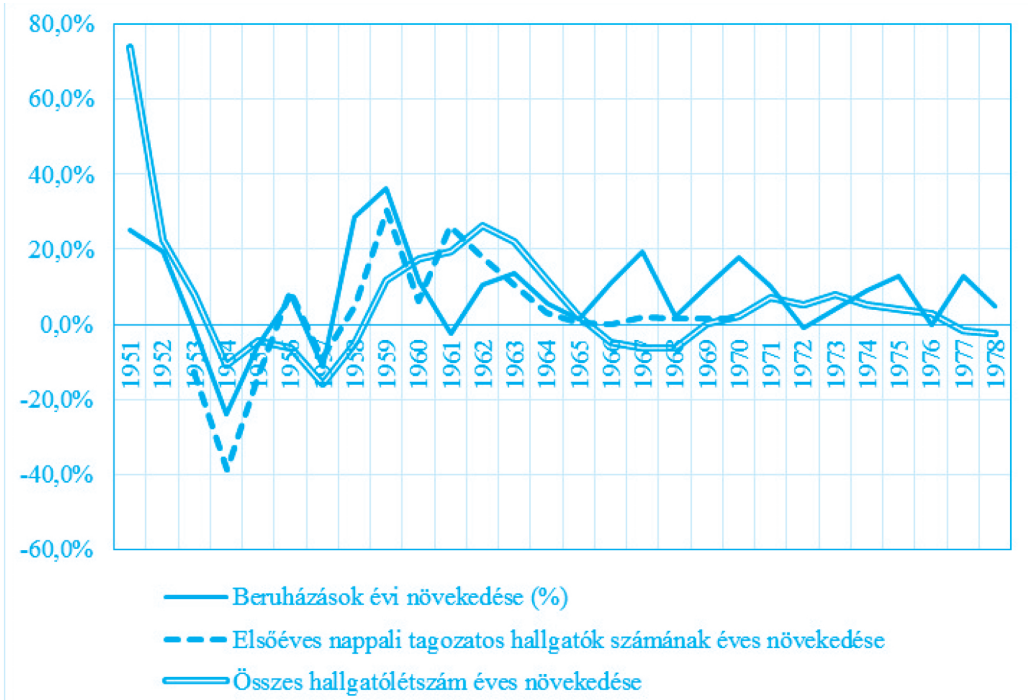

Forrás: Ladányi [1988], Bauer [1981] és a KSH [1996] adatai alapján saját számítás és szerkesztés

A beruházások éves százalékos alakulása valamint az elsőéves felsőoktatási hallgatók számának éves százalékos alakulása között (4. ábra) viszonylag robusztus korrelációt találunk (+0,6978), de az összes hallgatólétszám is (ami nyilvánvalóan tompítva tükrözi az ingadozást) viszonylag erős együttjárást mutat a beruházási ciklusokkal (+0,4067).

$\mathrm{Az}$ 1. éves hallgatói létszámnak ez a beruházási ciklushoz kapcsolódó ingadozása a hetvenes években és a nyolcvanas évek elején - a korábbi időszakokhoz képest - mérséklődött, amiben Ladányi Andor szerint szerepe van a hatvanas évek közepétől-végétől meginduló hosszú távú munkaerő-tervezésnek [Ladányi, 1988]. Azonban valójában sokkal inkább arról van szó, hogy a '80-as évek pangó magyar gazdaságához igazítva a felsőoktatást visszafogta az Országos Tervhivatal. 
5. ábra A felsőoktatási hallgatólétszám és a beruházási ciklus összefüggése Németországban

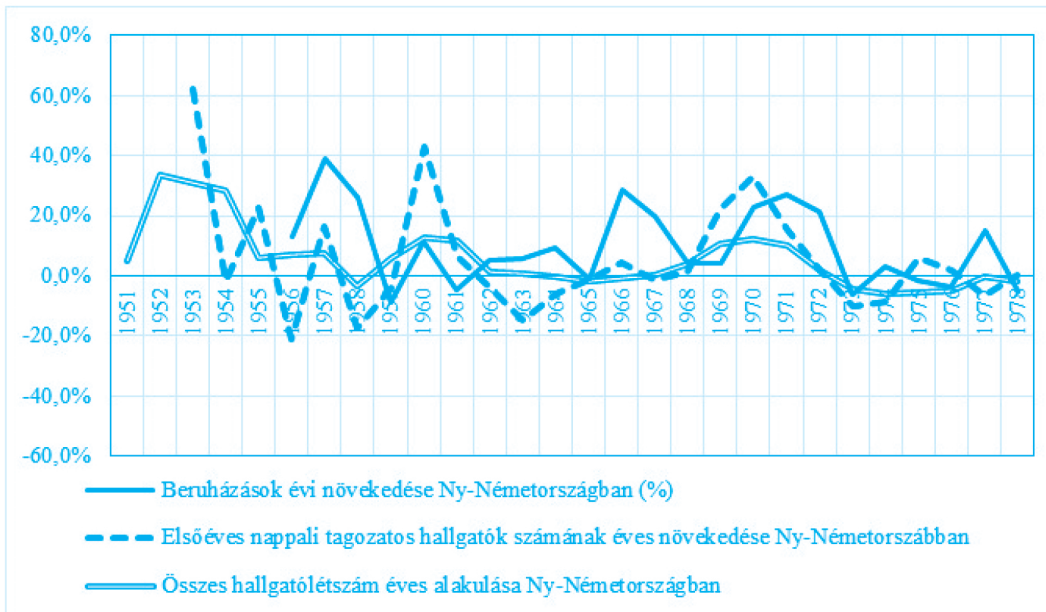

Forrás: Statistische Übersichten zur Sozialpolitik in Deutschland seit 1945 adatai alapján saját számítás

Érdemes a magyar adatokat a nyugatnémet adatokkal összehasonlítani (5. ábra). Első látásra nem sok különbség látszik a két ábra között, azon túl, hogy a német adatoknak kisebb az ingadozása. Kissé alaposabb elemzés azonban rávilágít arra, hogy miközben a magyar elsőéves felsőoktatási hallgatólétszám alakulás éves százaléka viszonylag szoros kapcsolatot mutat a beruházások éves alakulásával, ez Németország esetében nincs így. Magyarul: amennyiben ebből az egy összehasonlításból meg lehet ítélni, a beruházási ciklussal együttmozgó elsőéves létszám posztszocialista sajátosság.

Németország esetében nem a beruházási ciklussal mozog együtt a hallgatólétszám, azonban mégis van mozgása.

2. táblázat Az elsőéves és a teljes hallgatólétszám növekedésének kapcsolata a beruházások éves növekedésével

\begin{tabular}{|l|l|l|}
\hline & Magyarország & Németország \\
\hline $\begin{array}{l}\text { Korreláció az első éves hallgatólétszám növekedés (\%) és a } \\
\text { beruházások éves növekedése (\%) között }\end{array}$ & $\begin{array}{l}(1953-1970) \\
+0,6977\end{array}$ & $\begin{array}{l}(1956-1970) \\
+0,1587\end{array}$ \\
\hline $\begin{array}{l}\text { Korreláció a teljes hallgatólétszám növekedés (\%) és a } \\
\text { beruházások éves növekedése (\%) között }\end{array}$ & $\begin{array}{l}(1953-1970) \\
-0,2278\end{array}$ & $\begin{array}{l}(1956-1970) \\
-0,1342\end{array}$ \\
\hline
\end{tabular}

Forrás: Magyarország KSH adatai alapján, Németország Statistische Übersichten zur Sozialpolitik in Deutschland seit 1945 adatai alapján saját számítás 


\section{A hallgatólétszám INGAdozÁsA A PIACI ORSZÁgoKBAN}

A nem államszocialista országok esetében tapasztalt hallgatólétszám ingadozások okaira Margaret Archer már a 70-es évek végén rámutatott: „.... a kormányzó elit figyelemmel kíséri az oktatás fejlesztését a saját céljaival és a változó körülményekkel összefüggésben. Tétovázik nagy változást bevezetni, amíg sürgető bizonyítékok nem merülnek fel arra, hogy a jelenlegi politika nem működik vagy nem megfelelö”. [Archer, 1989:620-621]. A politikai nyomás vagy a körülmények kényszerítik ki a változást. Mint Sáska összegzi: „A centralizált rendszerek „stop-go” típusú változásmintájának oka a rendszerre jellemző sajátos interakció vagy érdekérvényesítés.” [Sáska, 1992:24] Azt is leszögezi, hogy Archer elmélete szerint „a ciklikusság a központosított oktatásirányítás kikerülhetetlen következménye” [Sáska, 1992:33]

Miután az elsős létszám nem áll a rendelkezésünkre, a jelenséget a felsőoktatás teljes részvételi hányadának (Gross Enrolment Ratio) ${ }^{9}$ alakulásával vizsgáljuk, ami lényegében az OECDországok jelentős részében lehetővé teszi a vizsgálódást 1970-től napjainkig. A Gross Enrolment Ratio azért is alkalmasabb az elemzésre, mint a puszta felsőoktatási létszám, mivel lényegében a demográfiai változásokat is figyelembe veszi, abban az értelemben, hogy nevezőjében a releváns korosztályi létszám szerepel.

\section{Gross Enrolment RATio és Az AUtonómia}

A központosítást az egyetemi autonómia szintjével tudjuk mérni - már amennyiben van erre valamilyen mutatószámunk. Elemzésünk következő célja tehát megvizsgálni egy-egy ország teljes felsőoktatási részvételi arányának alakulását, illetve annak ingadozását és összefüggését az egyetemi autonómiával. A felsőoktatási szféra viselkedésének és teljesítményének elemzése során egyik meghatározó tényezőként feltételezhető változó az autonómia (lásd erről pl. [Teichler, 2003]). Empirikus vizsgálatok is igazolták például a felsőoktatási rangsorokban elfoglalt hely és - többek között - az egyetemi autonómia [Aghion et al., 2007] közötti kapcsolatot. Aghion és munkatársai megállapítják, hogy az európai egyetemeknek a rangsorokban elfoglalt kedvezőtlen helyzete - az amerikaiakhoz viszonyítva - egyrészt annak tulajdonítható, hogy túl kevés Európában a felsőoktatási beruházás, kevesebb a fajlagos (egy hallgatóra jutó) kiadás, másrészt annak, hogy az európai egyetemeknek rossz a kormányzása, elégtelen az autonómiája és gyakran perverz ösztönzőktől szenvednek [Aghion et al., 2007]. Egy másik tanulmányban pedig arra mutattak rá, hogy az autonómia és az intézmények innovációs teljesítménye között van kapcsolat [Aghion et al., 2010].

Jelen elemzésünkben azt fogjuk megvizsgálni, hogy milyen kapcsolat van az egyetemi autonómia és a felsőoktatási teljes részvételi hányad ingadozásai között. Az egyetemi autonómia helyzetét az EUA (European Universities Association) 2017. és 2011. évi jelentése alapján érté-

\footnotetext{
${ }^{9}$ A Gross Enrolment Ratio az adott oktatási szintre beiratkozott hallgatók száma - életkortól függetlenül - az azonos iskolai végzettségnek megfelelő hivatalos iskolai korú népesség százalékában kifejezve. A felsőoktatási szintnél a középiskolai hivatalos érettségi kortól kezdve az 5 éves korosztályt alkalmazzák. Lásd: http://uis.unesco.org/en/glossary-term/gross-enrolment-ratio

Megjegyzés: A Gross Enrolment Ratiót gyakran Gross Enrollment Rationak írják - az utóbbi írásmód az amerikai angolban szokásos.
} 
kelhetjük [Pruvot - Esterman, 2017;, Estermann et al., 2011]. Az EUA az egyetemi autonómia négy dimenzióját minősíti: a szervezeti (7 indikátorral), a pénzügyi (11 indikátorral), a személyzeti (8 indikátorral) és az akadémiai (12 indikátorral) autonómiákat ${ }^{10} .29$ európai felsőoktatási rendszert értékelnek, amelyből itt 20 országot vizsgálunk meg ${ }^{11}$. (Sajnos ezek az autonómia-mutatók csak a 2000-es évek első évtizedére állnak rendelkezésre.)

Ha a 20 ország halmazán a demokrácia adatokat összevetjük a felsőoktatásban tanulók teljes részvételi hányadaival, akkor igen gyenge korrelációkat tapasztalunk, kivéve a szervezeti autonómiát, ahol azt látjuk, hogy minél nagyobb a szervezeti önállóság, annál kisebb a hallgatólétszám (azaz a részvételi hányad) változása 2010 és 2017 között. Ez azt az - egyébként nem igazán meglepő - összefüggést mutatja, hogy minél nagyobb egy országban az egyetemek szervezeti autonómiája, annál kisebb a felsőoktatási részvételi hányad ingadozása. Ha megnézzük a vizsgált húsz ország teljes felsőoktatási részvételi arányának alakulását az elmúlt évtizedben (2010 és 2017 között), akkor három jellegzetes fejlődési típust tudunk elkülöníteni.

Az egyik a visszaeső felsőoktatási részvételi arányú országok (6. ábra). Ebbe a csoportba elsősorban posztszocialista és déli országok tartoznak, valamint Izland. Közülük Magyarország és Szlovákia felsőoktatási részvételi aránya csökkent a legalacsonyabbra. Ezekre az országokra az jellemző, hogy - Lengyelország és Izland kivételével - az EUA értékelése szerint az egyetemeknek alacsony az akadémiai autonómiája. Ha hosszabb távon - 1990-től - nézzük a részvételi arány alakulását, akkor azt látjuk, hogy a jelenlegi visszaesést egy viszonylag hosszabb növekedési fázis előzte meg. Erre a csoportra tehát az jellemző, hogy a 90-es években alacsony 15-30\%os részvételi arányról indulva a 2000-es évek első évtizedére egy 55-90\%-os maximumot elérve radikális visszaesés következett be, amelynek nyomán a teljes részvételi arány 15-25 százalékpontot zuhanva 50-70\%-ra esett vissza a 2000-es évek második évtizedének végére.

\section{6. ábra A visszaeső felsőoktatási részvételi arányú országok}
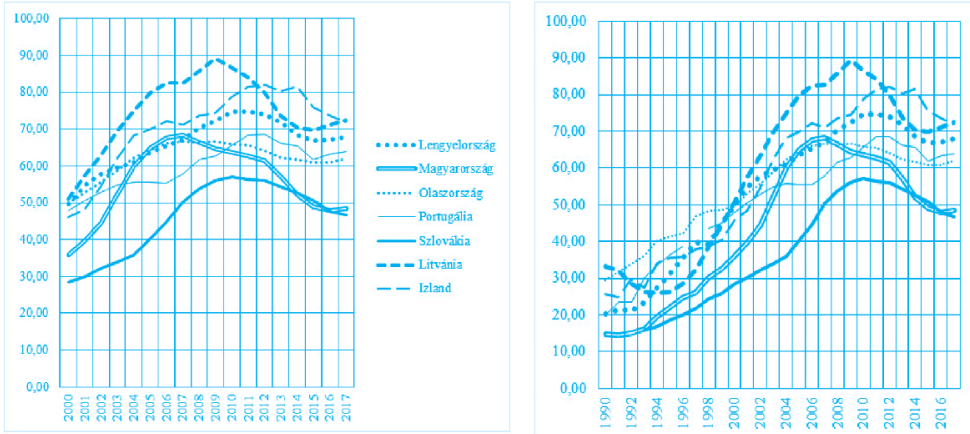

Forrás: UNESCO és Világbank adatbázisai alapján saját szerkesztés

\footnotetext{
${ }^{10}$ Módszertant lásd: https://www.university-autonomy.eu/

${ }^{11}$ Itt most kihagyjuk a németet, mert az EUA annak három tartományát vizsgálja, nem az ország egészét, valamint kihagyjuk a törököt, a szerbet és a szlovént, mert erről csak az egyik évben közölnek adatot, továbbá kihagyjuk a luxemburgit a hiányos részvételi adatok miatt. Így összesen 20 országot veszünk figyelembe.
} 
A másik csoport a viszonylag egyenletesen növekvő felsőoktatási részvételi arányú országok (7. ábra). Ez egy elég „vegyes” csoport kontinentális, dél-európai és északi posztszocialista országokkal. Ezekre az jellemző, hogy lényegében 1990 óta folyamatosan és nagyjából egyenletesen növekszik a felsőoktatás teljes részvételi aránya: az 1990-es 25-35\%-os arányról 2017-re elérte a 60-90\%-os hányadot. Ugyanakkor az EUA egyes autonómia-tényezői tekintetében nem sok közös van bennük.

7. ábra A növekvő felsőoktatási részvételi arányú országok
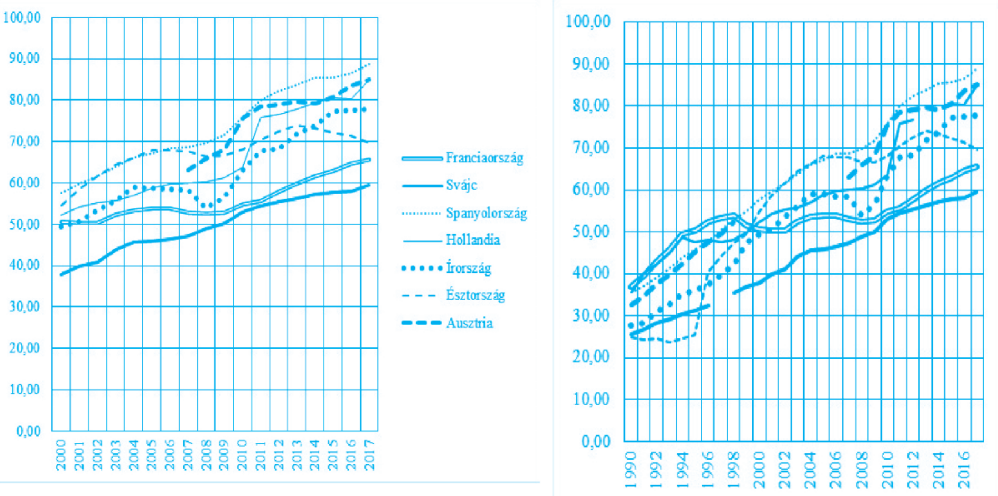

Forrás: UNESCO és Világbank adatbázisai alapján saját szerkesztés

8. ábra A stagnáló felsőoktatási részvételi arányú országok.
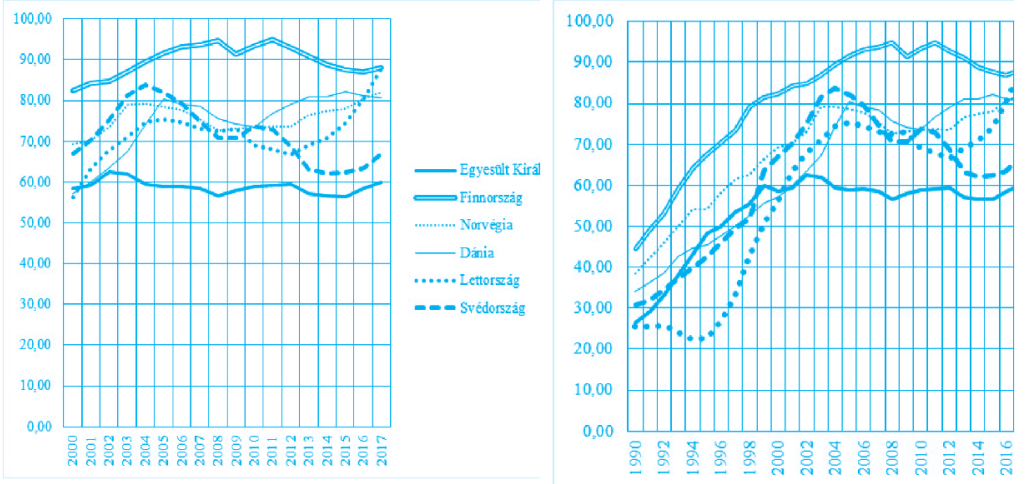

Forrás: UNESCO és Világbank adatbázisai alapján saját szerkesztés

A harmadik csoport a stagnáló felsőoktatási részvételi arányú országok. (8. ábra) Ide zömében északi országok tartoznak, de köztük találjuk Lettországot is, valamint az Egyesült Királyságot. Hosszabb távon vizsgálva ezeket csak az utóbbi húsz évben jellemzi a stagnálás. Lényegében inkább telítődésről lehetne beszélni. Ezek az országok az 1990-es 25-45\%-os arányról indulva a 
2000-es évek elején elérték a 60-90\%-os szintet, s azóta nagyjából ekörül stagnál a részvételi arányuk. Ezekre az országokra az jellemző, hogy - föleg az Egyesült Királyság, Finnország és Dánia - az EUA legtöbb autonómia mutatójában az élen állnak.

\section{A Gross Enrolment Ratio éves NÖVEKEDÉSI ÜTEMÉNEK INGADOZÁSA}

Eddig a felsőoktatás teljes részvételi hányadát vizsgáltuk, a továbbiakban annak ingadozásait fogjuk elemezni. A felsőoktatás teljes részvételi hányadának ingadozásait az elmúlt negyvenöt éves időszakban 22 OECD-ország ${ }^{12}$ esetében vizsgálva kitünik, hogy Magyarország a legnagyobb átlagos ingadozást mutató országok közé tartozik (Melléklet M1 táblázat). Ugyanakkor, ha ezt a 45 éves időszakot három szakaszra osztjuk (az államszocializmus utolsó 15 éve, a rendszerváltástól az ezredfordulóig és az ezredfordulótól napjainkig), akkor az látszik, hogy az első időszakban, az államszocializmus utolsó időszakában Magyarországon volt a legalacsonyabb a felsőoktatásban tanulók arányának az ingadozása (tegyük hozzá, hogy a növekedés is igen alacsony volt, az országok alsó harmadába tartoztunk).

9. ábra A Gross Enrolment Ratio éves növekedési ütemének (balra) és a ráta növekedési ütemének ingadozásának (jobbra) tizenötéves időszakonkénti átlaga - OECD átlag és Magyarország
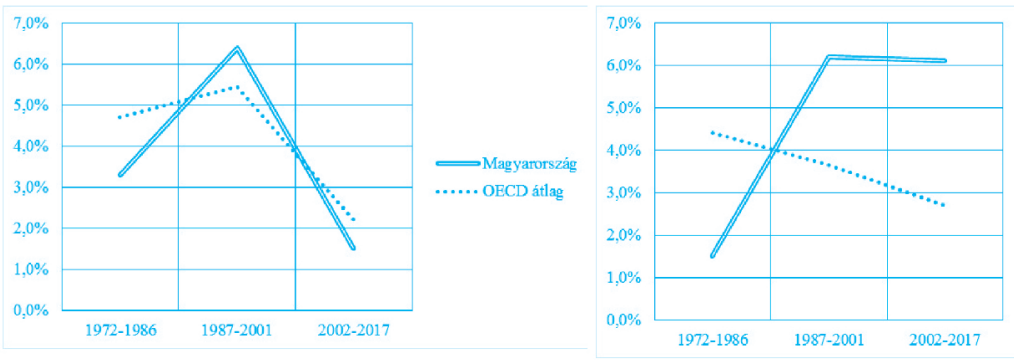

Forrás: UNESCO és Világbank adatbázisai alapján saját számítás és szerkesztés

Ugyanakkor Magyarországon mind a rendszerváltástól az ezredfordulóig, mind a napjainkig tartó tizenöt évben a legmagasabb, vagy majdnem a legmagasabb volt nálunk a felsőoktatási hallgatólétszám ingadozása a vizsgált országok között, miközben ez a két időszak a felsőoktatási hallgatólétszám növekedési ütemét tekintve két ellentétes periódus volt. Az elsőben - a rendszerváltás után - Magyarország a magas növekedési ütemű országok közé tartozott, mivel ezt az időszakot a fejlett országokhoz való felzárkózás oktatáspolitikája jellemezte [Polónyi 2015], az ezt követő időszakban pedig a közepesen alacsony növekedési ütemű országok közé.

${ }^{12}$ A 22 vizsgált országot lásd Melléklet M1 táblázat. Ezek azok az országok, amelyekre 1970 illetve 1971 óta nagyobb adathiány nélkül rendelkezésre áll az UNESCO illetve a Világbank adatbázisában a felsőoktatás teljes részvételi hányadának adatsora. 
Ha a tizenöt éves szakaszok növekedési ütemét és az ütem ingadozási átlagát vizsgálva összehasonlítjuk a magyar és az OECD országátlag adatokat (9. ábra), elég jól látszik, hogy miközben a hazai felsőoktatási teljes részvételi hányad növekedése közel hasonlóan alakul az OECD átlaghoz, addig a növekedési ütem ingadozásának alakulása jelentősen eltér attól. Ez utóbbi esetében az OECD átlag csökkenő tendenciát mutat, a hazai adaton viszont a magas ingadozás állandósulását láthatjuk.

Ha a korábbiakban látottakra is visszatekintünk, akkor azt állapíthatjuk meg, hogy a magyar felsőoktatás növekedési ütemének ingadozása mind az államszocializmus kezdeti időszakában (1970-ig), majd a rendszerváltás utáni időszakokban is nemzetközi összehasonlításban is kiemelkedően magas értékeket mutat.

\section{A Gross Enrolment Ratio éves NÖVEKEDÉSI ÜTEME ÉS AZ AUTONÓMIA}

A következőkben a felsőoktatási Gross Enrolment Ratio éves változásának kapcsolatát vizsgáljuk meg az autonómia mutatókkal a 2000-es évekre (lásd Melléklet M2. táblázat valamint 10. ábra) Az adatok tanúsága szerint - a vizsgált országok halmazán - az akadémiai autonómia és a szervezetalakítási autonómia látszik - mindkettő negatív korreláció szerint - együttmozogni a részvételi hányad éves alakulásának átlagtól való eltérésével. (Az autonómia mutatók átlaga is hasonló tendenciát mutat, bár alacsonyabb korrelációval). Magyarul ezt úgy interpretálhatjuk, hogy minél kisebb az akadémiai és a szervezetalakítási autonómia, annál nagyobb a létszámingadozás.

10. ábra A Gross Enrolment Ratio és az EUA autonómia mutatók kapcsolata

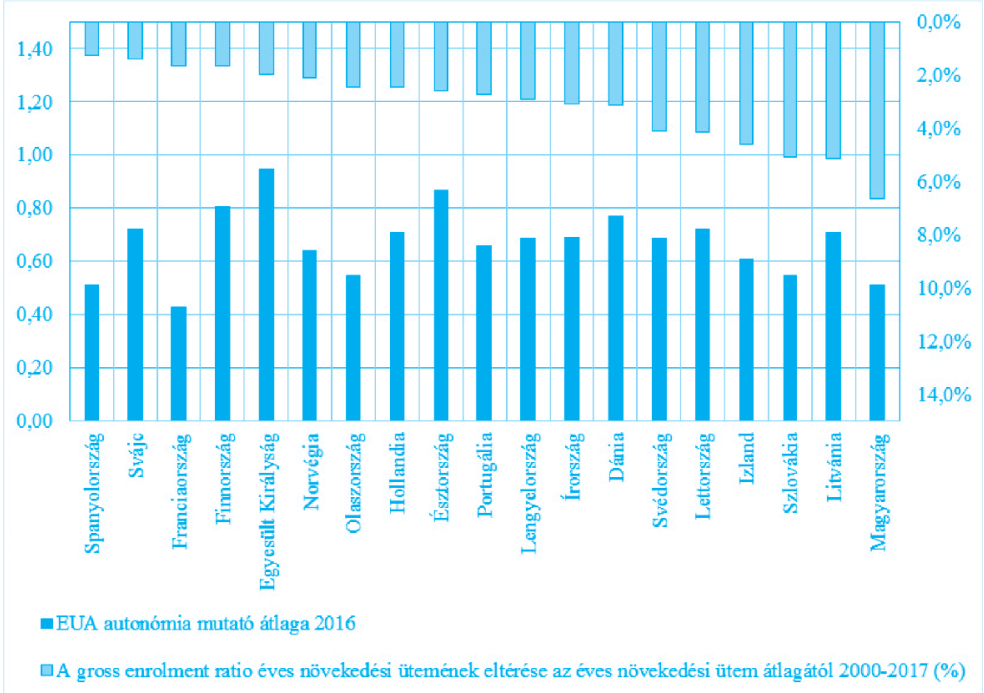

Forrás: UNESCO és Világbank adatbázisai alapján saját számítás és szerkesztés

Az adatokból jól látszik, hogy a három legnagyobb részvételi hányad ingadozást mutató ország három posztszocialista ország (Szlovákia, Litvánia, Magyarország), s közülük is nálunk a legma- 
gasabb ez az ingadozás. Az is látszik, hogy e három ország közül Szlovákiában és Magyarországon az EUA autonómia mutatók átlaga is igen szerény. Ugyanakkor ugyancsak igen alacsony - és ezzel Szlovákia és Magyarország szintjén áll - az autonómia mutatók átlaga Spanyországban és Franciaországban, viszont e két országban a létszámingadozás a legkisebb. A legkisebb létszámnövekedés ingadozást mutató öt ország között ezen a két országon kívül Svájc, Finnország és az Egyesült Királyság található. Ezeknek a nemzeteknek a felsőoktatási létszámának változására viszont egyértelmü stabilitás jellemző, s egyben magas autonómia is.

Összességében tehát úgy tünik, hogy a 90-es évek óta is sok országra érvényes az Archer-féle modell. Elsősorban a posztszocialista és néhány északi országok esetében ismerhető fel a stop-go mechanizmus hosszú távú érvényesülése.

\section{Az ÉVES GAZDASÁGI FEJLŐDÉS ÉS A KOROSZTÁLYI LÉTSZÁM INGADOZÁSA ÉS A GROSS ENROLMENT RATIO ÉVES NÖVEKEDÉSI ÜTEME KÖZÖTTI KAPCSOLAT}

Befejezésül további két változót is bevonunk egy rövid elemzés erejéig: a GDP éves ingadozásait, valamint a felsőoktatás szempontjából releváns korosztály létszámának ingadozásait.

Elöször azt elemezzük, hogy mennyire függ össze a felsőoktatás teljes részvételi hányadának éves ingadozása a GDP éves növekedésének ingadozásával.

Ha megvizsgáljuk azt, hogy a felsőoktatási teljes részvételi hányad ingadozásának az átlagtól való eltérése hogyan függ össze a GDP éves változásának ingadozásával, valamint az EUA autonómia mutatók átlagával akkor azt találjuk, hogy a GDP ingadozásával pozitív kapcsolatban áll a létszámingadozás $(+0,5127)$, az autonómia mutatókkal pedig negatív korrelációs kapcsolatban $(-0,2860)^{13}$ (Melléklet M3. táblázat).

Ha a vizsgálódásba bevonjuk a felsőoktatás szempontjából releváns korcsoportot is, akkor azt találjuk, hogy a GDP ingadozása pozitív kapcsolatban áll a létszámingadozással $(+0,4802)$, az autonómia mutatókkal pedig igen gyenge negatív korrelációs kapcsolatban $(-0,2041)$, a 15-24 éves korcsoport ${ }^{14}$ létszámingadozása pedig ismét csak pozitív korrelációt $(+0,3819)$ mutat azzal (Melléklet M4. táblázat)

Érdemes megemlíteni, hogy ha az elemzésbe nem az autonómia értékek átlagát, hanem mind a négy autonómia mutató értékét bevonjuk, akkor a szervezeti autonómia és az akadémiai autonómia az, ami számottevő együttjárást (mindkettő -0,3 körüli negatív korreláció) mutat a Gross Enrolment Ratio ingadozásaival.

\section{KoNKLÚZIó}

Célunk az volt, hogy a felsőoktatás fejlődésében tapasztalható ingadozásokat elemezzük. Az elemzés a felsőoktatás elmúlt mintegy ötven évének hazai és nemzetközi fejlődését vette górcső alá.

\footnotetext{
${ }^{13}$ A két tényező változó (azaz a GDP növekedés ingadozása és az autonómia mutatók) között +0,2249 parciális korrelációs együtthatót találunk.

${ }^{14}$ A felsőoktatás szempontjából releváns korcsoport valójában a 18-24 éves, azonban az UNESCO adatbázisban a 15-24 éves korcsoport létszáma áll rendelkezésre a vizsgálatba vont országok esetében.
} 
A felsőoktatás növekedésében tapasztalható ingadozások nemzetközi összehasonlításban azt mutatják, hogy a hazai ciklikusság az egyik legnagyobb mind 1970 elött, mind 1987 után. Az államszocialista időszak felsőoktatási ciklikussága régről ismert jelenség [Bauer, 1981; Bródy 2000], ugyanakkor az ezredforduló után tapasztalható ingadozásnak kevésbé vizsgáltak az okai.

Vizsgálatainkat úgy interpretálhatjuk, hogy a felsőoktatási teljes részvételi hányad éves ingadozásait a GDP és a releváns korosztály létszámának éves ingadozásai növelik, az egyetemi autonómia növekedése pedig csökkenti.

Elemzésünk tehát arra utal, hogy ezeknek az ingadozásoknak a GDP és a korosztályi létszám ingadozásai mellett a felsőoktatási intézmények autonómiájában - annak korlátozásában - lelhetők meg a magyarázatai.

\section{Felhasznált IRODALOM}

Aghion, Ph., M. Dewatripont, C. Hoxby, A. Mas-Colell, A. Sapir (2007): Way Reform Eurpe's Universities. Bruegelpolicybrief 2007/4 https://www.researchgate.net/publication/29997993 Why_Reform_Europe\%27s_Universities_Bruegel_policy_brief_200704_September_2007 (Letöltés 2020. 04.10.)

Aghion, Ph., M. Dewatripont, C. Hoxby, A. Mas-Colell, A. Sapir (2010): “The Governance and Performance of Universities: Evidence from Europe and the US.” Economic Policy 25 (61) (January): 7-59.

Archer, M. S. (1979): Social Origins of Educational Systems. London, Sage.

Bauer T. (1981): Tervgazdaság, beruházás, ciklus, KJK. Budapest.

Bródy A. (2000): A magyar felsőoktatás ingadozásairól, Közgazdasági Szemle, 2000. október pp. $817-83.1$

Digest of Eduaction Statistics IES-NCES dt18_303.10.asp (Letöltés 2020. 02. 01.)

https://nces.ed.gov/programs/digest/d18/tables/

Estermann Th. - Nokkola T. - Stein, M. (2011): University Autonomy in Europe II. The Scorecard. EUA, Brüssel https://eua.eu/downloads/publications/university\%20autonomy\%20in\%20 europe\%20ii\%20-\%20the\%20scorecard.pdf (Letöltés 2020. 02. 01.)

Ladányi A (1988): Mennyiségi fejlődés és strukturális változások: a felsőoktatás útja a felszabadulás után. HYPERLINK „https://www.antikvarium.hu/kiado/oktataskutato-intezet-10403” Oktatáskutató Intézet, Budapest.

Magyarország népessége és gazdasága Múlt és jelen, KSH, 1996

Polónyi I. (2015): A felsőoktatás-politika átalakulásai. Iskolakultúra, 5-6. sz. pp.3-14.

Polónyi, I (2016): Pedagógusképzés 1945 után oktatásgazdasági aspektusból In: Tóth, P.; Holik, I. (szerk.): Új kutatások a neveléstudományokban 2015: Pedagógusok, tanulók, iskolák - az értékformálás, az értékközvetítés és az értékteremtés világa. Budapest, ELTE Eötvös Kiadó, pp. 227-234.

Pruvot E. B. - Esterman Th. (2017): University Autonomy in Europe III The Scorecard 2017. EUA, Brüssel https://www.university-autonomy.eu/ (Letöltés 2020. 02. 10.)

Sáska G. (1992): Ciklikusság és centralizáció. A központositott tanügyigazgatás és a felnőttoktatás esete. Educatio Kiadó. Budapest http://www.mek.oszk.hu/14600/14605/pdf/14605.pdf (Letöltés 2020. 02. 10.)

Snyder Th. D (ed 1993): 120 Years of American Education: A Statistical Portrait. National Center for Education Statistics https://nces.ed.gov/pubs93/93442.pdf , (Letöltés 2020. 02. 01.) 
Steiner, A. (2006): Statistische Übersichten zur Sozialpolitik in Deutschland seit 1945 https:// www.bmas.de/SharedDocs/Downloads/DE/PDF-Publikationen/fb-f352-statistischeuebersichten-zur-sozialpolitik-in-deutschland-seit-1945.pdf?_blob=publicationFile\&v=2 (Letöltés 2020. 02. 10.)

Teichler, U. (2003): Az európai felsőoktatási reformok főbb kérdései, Educatio 2003/1

\section{MellékLeT}

M1. táblázat A Gross Enrolment Ratio éves növekedésének ingadozásai a felsőoktatásban

\begin{tabular}{|c|c|c|c|c|c|c|c|c|c|c|c|}
\hline & \multicolumn{2}{|c|}{$1972-2017$} & & \multicolumn{2}{|c|}{ 1972-1986 } & & \multicolumn{2}{|c|}{$1987-2001$} & & \multicolumn{2}{|c|}{$2002-2017$} \\
\hline & 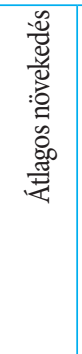 & 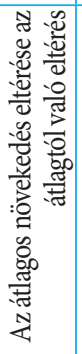 & & 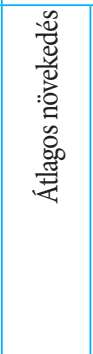 & 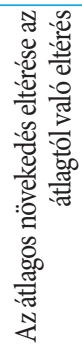 & & 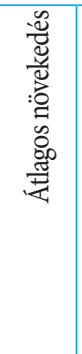 & 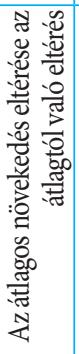 & & 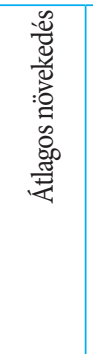 & 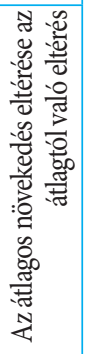 \\
\hline Svájc & $0 \%$ & $1,8 \%$ & Magy & $3,3 \%$ & $1,5 \%$ & Spanyolo. & $5,1 \%$ & $0,9 \%$ & & $1,9 \%$ & $1,2 \%$ \\
\hline Belgium & $3,4 \%$ & $2,4 \%$ & Hollandia & $3,3 \%$ & $1,9 \%$ & Svájc & $4,1 \%$ & $0,9 \%$ & Spanyolo. & $2,5 \%$ & $1,2 \%$ \\
\hline Franciaország & $2,8 \%$ & $2,6 \%$ & Franciao. & $3,2 \%$ & $2,4 \%$ & Dánia & $5,0 \%$ & $1,6 \%$ & Svájc & $2,6 \%$ & $1,3 \%$ \\
\hline Hollandia & $3,3 \%$ & $2,6 \%$ & Svájc & $5,3 \%$ & $2,5 \%$ & Írország & $5,5 \%$ & $2,0 \%$ & Franciao. & $1,7 \%$ & $1,5 \%$ \\
\hline Izrael & $2,6 \%$ & $3,0 \%$ & Belgium & $4,2 \%$ & $2,8 \%$ & Izrael & $2,7 \%$ & $2,2 \%$ & Finno. & $0,3 \%$ & $1,8 \%$ \\
\hline Írország & $4,5 \%$ & $3,3 \%$ & Egy. Kir. & $2,7 \%$ & $3,1 \%$ & Belgium & $4,3 \%$ & $2,3 \%$ & & $0,1 \%$ & $2,0 \%$ \\
\hline Norvégia & $3,7 \%$ & $3,4 \%$ & Norvégia & $4,4 \%$ & $3,3 \%$ & Finno & $6,3 \%$ & $2,4 \%$ & Norvégia & $1,0 \%$ & $2,1 \%$ \\
\hline Olaszország & $3,0 \%$ & $3,4 \%$ & Lengyelo. & $1,9 \%$ & $3,3 \%$ & Chile & $5,4 \%$ & $2,7 \%$ & Mexikó & $4,1 \%$ & $2,1 \%$ \\
\hline Spanyolország & $5,4 \%$ & $3,5 \%$ & Olaszo. & $2,9 \%$ & $3,9 \%$ & Olaszo. & $5,0 \%$ & $2,8 \%$ & Olaszo. & $1,0 \%$ & $2,3 \%$ \\
\hline Dánia & $3,3 \%$ & $3,6 \%$ & Izrael & $4,1 \%$ & $3,9 \%$ & Norvégia & $6,0 \%$ & $2,9 \%$ & Lengyelo. & $1,4 \%$ & $2,4 \%$ \\
\hline Mexikó & $4,6 \%$ & $3,8 \%$ & Izland & $5,4 \%$ & $4,3 \%$ & Hollandia & $3,7 \%$ & $3,0 \%$ & Görögo. & $5,6 \%$ & $2,4 \%$ \\
\hline Egyesült & $3,2 \%$ & $3,8 \%$ & Görögo. & $4,3 \%$ & $4,5 \%$ & Mexikó & $2,1 \%$ & $3,5 \%$ & Korea & $1,1 \%$ & $2,5 \%$ \\
\hline Chile & $4,9 \%$ & $4,1 \%$ & Írország & $5,4 \%$ & $4,7 \%$ & Svédo. & $5,9 \%$ & $3,6 \%$ & Portugália & $1,5 \%$ & $2,5 \%$ \\
\hline Lengyelország & $3,7 \%$ & $4,2 \%$ & Dánia & $3,1 \%$ & $4,9 \%$ & Franciao. & $3,8 \%$ & $3,6 \%$ & Hollandia & $2,9 \%$ & $2,5 \%$ \\
\hline Finnország & $4,6 \%$ & $4,5 \%$ & Mexikó & $7,7 \%$ & $5,2 \%$ & Egy. Kir. & $7,1 \%$ & $4,1 \%$ & Izrael & $1,3 \%$ & $2,7 \%$ \\
\hline Svédország & $2,7 \%$ & $4,9 \%$ & Cseho & $4,2 \%$ & $5,3 \%$ & Korea & $6,2 \%$ & $4,8 \%$ & Chile & $5,5 \%$ & $3,1 \%$ \\
\hline Görögország & $5,5 \%$ & $4,9 \%$ & Portugália & $4,3 \%$ & $6,2 \%$ & Lengyelo & $8,1 \%$ & $5,1 \%$ & Dánia & $1,9 \%$ & $3,3 \%$ \\
\hline Izland & $4,6 \%$ & $4,9 \%$ & Chile & $3,7 \%$ & $6,4 \%$ & Portugália & $9,8 \%$ & $5,8 \%$ & Írország & $2,8 \%$ & $3,3 \%$ \\
\hline Magyarország & $3,7 \%$ & $5,1 \%$ & Spanyolo. & $8,8 \%$ & $6,7 \%$ & Izland & $5,9 \%$ & $5,9 \%$ & Svédo. & $-0,2 \%$ & $3,9 \%$ \\
\hline Portugália & $5,1 \%$ & $5,2 \%$ & Korea & $11,5 \%$ & $7,0 \%$ & Cseho. & $4,6 \%$ & $6,1 \%$ & Izland & $2,7 \%$ & $4,3 \%$ \\
\hline Csehország & $4,6 \%$ & $5,3 \%$ & Finno. & $7,4 \%$ & $7,8 \%$ & Magyaro. & $6,4 \%$ & $6,2 \%$ & Cseho. & $5,0 \%$ & $4,6 \%$ \\
\hline Korea & $6,2 \%$ & $5,8 \%$ & Svédo. & $2,6 \%$ & $5,4 \%$ & Görögo. & $6,7 \%$ & $7,8 \%$ & Magyaro. & $1,5 \%$ & $6,1 \%$ \\
\hline
\end{tabular}


M2. táblázat A felsőoktatási teljes részvételi ráta (gross enrolment ratio) és az EUA autonómia mutatók korrelációs kapcsolata

\begin{tabular}{|c|c|c|c|c|c|c|}
\hline & $\begin{array}{l}\text { A Gross Enrolment } \\
\text { Ratio átlagos éves } \\
\text { növekedési ütemének } \\
\text { eltérése az éves } \\
\text { növekedési ütem } \\
\text { átlagától 2000-2017 }\end{array}$ & 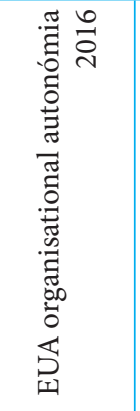 & 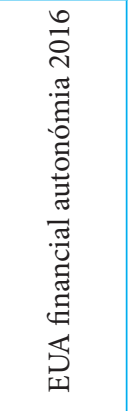 & 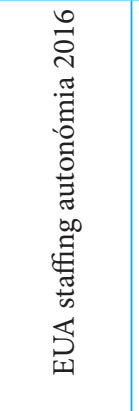 & 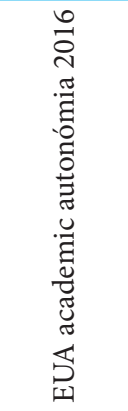 & 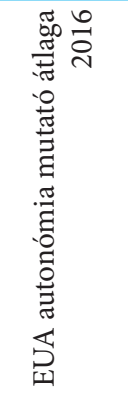 \\
\hline Spanyolország & $1,25 \%$ & 0,60 & 0,40 & 0,47 & 0,58 & 0,51 \\
\hline Svájc & $1,37 \%$ & 0,56 & 0,62 & 0,95 & 0,75 & 0,72 \\
\hline Franciaország & $1,63 \%$ & 0,56 & 0,33 & 0,42 & 0,39 & 0,43 \\
\hline Finnország & $1,67 \%$ & 0,91 & 0,51 & 0,92 & 0,88 & 0,81 \\
\hline Egyesült Királyság & $1,98 \%$ & 1,00 & 0,90 & 0,96 & 0,92 & 0,95 \\
\hline Norvégia & $2,08 \%$ & 0,77 & 0,29 & 0,62 & 0,87 & 0,64 \\
\hline Olaszország & $2,45 \%$ & 0,59 & 0,62 & 0,42 & 0,55 & 0,55 \\
\hline Hollandia & $2,46 \%$ & 0,76 & 0,78 & 0,72 & 0,57 & 0,71 \\
\hline Észtország & $2,60 \%$ & 0,82 & 0,69 & 1,00 & 0,95 & 0,87 \\
\hline Portugália & $2,73 \%$ & 0,74 & 0,75 & 0,62 & 0,52 & 0,66 \\
\hline Lengyelország & $2,91 \%$ & 0,64 & 0,47 & 0,84 & 0,78 & 0,68 \\
\hline Írország & $3,07 \%$ & 0,71 & 0,71 & 0,42 & 0,92 & 0,69 \\
\hline Dánia & $3,14 \%$ & 0,94 & 0,53 & 0,86 & 0,75 & 0,77 \\
\hline Svédország & $4,09 \%$ & 0,62 & 0,44 & 0,96 & 0,72 & 0,69 \\
\hline Lettország & $4,16 \%$ & 0,56 & 0,93 & 0,89 & 0,50 & 0,72 \\
\hline Izland & $4,57 \%$ & 0,45 & 0,55 & 0,67 & 0,77 & 0,61 \\
\hline Szlovákia & $5,09 \%$ & 0,40 & 0,64 & 0,59 & 0,55 & 0,55 \\
\hline Litvánia & $5,15 \%$ & 0,82 & 0,73 & 0,83 & 0,44 & 0,71 \\
\hline Magyarország & $6,66 \%$ & 0,60 & 0,44 & 0,49 & 0,52 & 0,51 \\
\hline $\begin{array}{l}\text { Korreláció a Gross } \\
\text { Enrolment Ratio } \\
\text { ingadozásának átlagtól } \\
\text { való eltérésével }\end{array}$ & & $-0,32127$ & 0,10986 & $-0,06694$ & $-0,32455$ & $-0,20409$ \\
\hline
\end{tabular}

Forrás: Világbank illetve EAU (Pruvot - Esterman 2017) adatai alapján saját számítás 
M3. táblázat A felsőoktatás teljes részvételi hányada és a GDP éves ingadozásainak változásai valamint az egyetemi autonómia kapcsolata

\begin{tabular}{|c|c|c|c|}
\hline & $\begin{array}{l}\text { A Gross Enrolment Ratio } \\
\text { éves ingadozásának } \\
\text { változási átlaga (2000-2018) }\end{array}$ & $\begin{array}{c}\text { A GDP éves } \\
\text { ingadozásának } \\
\text { változási átlaga (2010- } \\
\text { 2018) }\end{array}$ & $\begin{array}{c}\text { Az EUA autonómia } \\
\text { mutatóinak átlaga } \\
(2016)\end{array}$ \\
\hline $\begin{array}{l}\text { A Gross Enrolment Ratio } \\
\text { éves ingadozásának } \\
\text { változási átlaga (2000-2018) }\end{array}$ & 1 & & \\
\hline $\begin{array}{l}\text { A GDP éves ingadozásának } \\
\text { változási átlaga (2010-2018) }\end{array}$ & $0,5127^{\star * *}$ & 1 & \\
\hline $\begin{array}{c}\text { Az EUA autonómia } \\
\text { mutatóinak átlaga (2016) }\end{array}$ & $-0,2860^{\star * *}$ & $0,2249^{* * *}$ & 1 \\
\hline
\end{tabular}

Megjegyzés. ${ }^{* * *} \mathrm{p}<0,001$

Forrás: M2 táblázat adatai alapján saját számítás

M4. táblázat A felsőoktatás teljes részvételi hányada, a GDP és a 15-24 éves korcsoport éves ingadozásainak változásai valamint az egyetemi autonómia kapcsolata

\begin{tabular}{|c|c|c|c|c|}
\hline & $\begin{array}{l}\text { A Gross Enrolment } \\
\text { Ratio éves } \\
\text { ingadozásának } \\
\text { változási átlaga } \\
(2000-2018)\end{array}$ & $\begin{array}{l}\text { A GDP éves } \\
\text { ingadozásának } \\
\text { változási átlaga } \\
(2010-2018)\end{array}$ & $\begin{array}{c}\text { Az EUA } \\
\text { autonómia } \\
\text { mutatóinak } \\
\text { átlaga (2016) }\end{array}$ & $\begin{array}{l}\text { A 15-24 éves népes- } \\
\text { ség létszámváltozá- } \\
\text { sának átlagától való } \\
\text { eltérés }\end{array}$ \\
\hline $\begin{array}{c}\text { A Gross Enrolment } \\
\text { Ratio éves } \\
\text { ingadozásának változási } \\
\text { átlaga (2000-2018) }\end{array}$ & 1 & & & \\
\hline $\begin{array}{c}\text { A GDP éves } \\
\text { ingadozásának változási } \\
\text { átlaga }(2010-2018) \\
\end{array}$ & $0,4802^{\star \star \star}$ & 1 & & \\
\hline $\begin{array}{c}\text { Az EUA autonómia } \\
\text { mutatóinak átlaga (2016) }\end{array}$ & $-0,2041^{\star * *}$ & $0,0951^{* * *}$ & 1 & \\
\hline $\begin{array}{l}\text { A 15-24 éves népesség } \\
\text { létszámváltozásának } \\
\text { átlagától való eltérés }\end{array}$ & $0,3819^{\star * *}$ & $0,5536^{\star * *}$ & $0,3918^{\star * *}$ & 1 \\
\hline
\end{tabular}

Megjegyzés. ${ }^{* * *} \mathrm{p}<0,001$

Forrás: M2 táblázat adatai alapján saját számítás 